\begin{tabular}{l|l}
\hline Notaice & $\begin{array}{l}\text { e-ISSN: 2655-9404 } \\
\text { DOI: } 10.20473 / \text { ntr.v2i1.13167 }\end{array}$ \\
Vol. 02 No. 1, Februari 2019 & .
\end{tabular}

Article history: Submitted 6 December 2018 ; Accepted 11 January 2019; Available online 1 February 2019.

\title{
Konsep Pengelolaan Sumber Daya Air Pasca Putusan Mahkamah Konstitusi Nomor 85/PUU-XI/2013
}

\author{
Aqiel al Rosyid Noor dan Alfian Khunaefi \\ aqiel.rosyid@gmail.com dan khunaefialfian@gmail.com \\ Universitas Airlangga
}

\begin{abstract}
On 2013 Supreme court nullified Law Number 7 Year 2004 on water resources management, and reenacted Law Number 11 Year 1974 on irrigation. Law Number 7 Year 2004 considered to oppose Constitution because right to utilize water can be given to the private party or individual. Although, right to utilize water by private party have been constituted under Law Number 7 Year 2004 also have been nullified by Supreme Court; however it doesn't close any possibilities for any private party or individual to be able to manage water resource, because on Law Number 11 Year 1974 constitute that legal entitiy, social enterprise or individual authorize to utilize water and/or water resource with certain requirement through gained permission from government. That is the concept of management of water resources that can also be given to the private sector, but the issuance of these permits must fulfill certain conditions to prevent unconstitutionality in the application of the Irrigation Law.
\end{abstract}

Keywords: Supreme Court; Management; Water Resource.

\begin{abstract}
Abstrak
Tahun 2013 Mahkamah Konstitusi membatalkan Undang-Undang Nomor 7 Tahun 2004 tentang Pengelolaan Sumber Daya Air, dan memberlakukan kembali Undang-Undang Nomor 11 tahun 1974 Tentang Pengairan. UU Nomor 7 Tahun 2004 dianggap bertentangan dengan Konstitusi karena hak guna usaha air yang dapat diberikan kepada badan usaha swasta atau perorangan. Meskipun hak guna usaha air oleh swasta yang sebelumnya telah diatur UU Nomor 7 Tahun 2004 telah dibatalkan oleh Mahkamah Konstitusi, namun tidak menutup kemungkinan adanya pihak swasta maupun perorangan yang dapat mengelola sumber daya air, karena dalam UU Nomor 11 Tahun 1974 mengatur bahwa badan hukum atau badan sosial atau perorangan dapat melakukan pengusahaan air dengan syarat harus memperoleh izin dari Pemerintah. UU Nomor 11 Tahun 1974 menerapkan konsep yang sama mengenai hak guna air. Yaitu adanya konsep pengelolaan sumber daya air yang juga dapat diberikan kepada swasta, namun pemeberian izin tersebut harus memenuhi syarat-syarat tertentu untuk mencegah inkonstitusinalitas dalam penerapan UU Pengairan.
\end{abstract}

Kata Kunci: Mahkamah Konstitusi; Pengelolaan; Sumber Daya Air.

\section{Latar Belakang}

Sejak Tahun 2013 Mahkamah Konstitusi telah memberikan putusan pembatalan terhadap Undang-Undang Nomor 7 Tahun 2004 tentang Pengelolaan Sumber Daya Air (selanjutknya disebut UU SDA), alasan dibatalkannya UU SDA adalah dikarenakan adanya pengajuan pembatalan dan undang-undang tersebut dianggap bertentangan dengan konstitusi atau Undang-Undang Dasar Negara Republik Indonesia Tahun 19945 (selanjutnya disebut UUD NRI 1945), 
lalu memberlakukan kembali Undang-Undang Pengelolaan Sumber Daya Air sebelumnya yakni Undang-Undang Nomor 11 Tahun 1974 tentang Pengairan (selanjutnya disebut UU Pengairan) untuk mencegah terjadinya kekosongan hukum pasca dibatalkannya UU SDA.

Salah satu pasal dalam UU SDA yang dianggap bertentangan dengan Konstitusi ialah pasal 9 yakni terkait hak guna usaha air yang dapat diberikan kepada badan usaha swasta atau perorangan, tentunya konsep ini dianggap bertentangan dengan UUD NRI 1945 khususnya pada Pasal 33 ayat (3) yang mengatur tentang penguasaan negara atas bumi, air, dan kekayaan yang terkandung didalamnya serta dimanfaatkan untuk sebesar-besarnya kepentingan rakyat. Konsep penguasaaan negara tersebut sebenarnya telah diatur dipasal sebelumnya dalam UU SDA, yakni pasal 6 menyebutkan bahwa penguasaan atas sumber daya air tersebut diselenggarakan oleh negara dalam hal ini pemerintah atau pemerintah daerah atau masyarakat adat dengan hak ulayat yang dimiliki sepanjang hak tersebut masih tetap ada dan telah diatur dalam peraturan daerah setempat.

Dengan berlakunya kembali UU Pengairan, pada tahun 2015 Pemerintah kembali mengesahkan Peraturan Pemerintah sebagai Peraturan Pelaksana UU Pengairan, yakni Peraturan Pemerintah Nomor 121 Tahun 2015 tentang Pengusahaan Sumber Daya Air (selanjutnya disebut PP PSDA). Jika melihat lebih lanjut dalam pengaturan dalam PP PSDA memang telah meniadakan konsep hak guna air, baik itu hak guna usaha air maupun hak guna pakai air yang sebelumnya diatur dalam UU SDA, dimana Hak Guna Usaha Air ini lah yang menjadikan UU SDA dianggap inkonstitusional mengingat air merupakan kebutuhan bagi setiap rakyat, dan juga bukan hanya manusia yang membutuhkan air tetapi semua makhluk hidup yang ada dimuka bumi, sehingga air merupakan zat yang tak tergantikan, ${ }^{1}$ namun undangundang memberikan peluang bagi swasta atau perorangan untuk menguasai, mengelola, dan tentunya mengusahakan air yang semestinya menjadi hak dari seluruh rakyat Indonesia untuk memperoleh keuntungan tersendiri.Meskipun

1 Ria Casmi Arrsa, 'Telaah Sociolegal Terhadap Terwujudnya Kedaulatan Hak Atas Sumber Daya Air' (2015) 4 Jurnal Rechtvinding.[222]. 
hak guna usaha air yang sebelumnya telah diatur UU SDA telah dibatalkan oleh Mahkamah Konstitusi, namun tidak menutup kemungkinan adanya pihak swasta maupun perorangan yang dapat mengelola sumber daya air. Dalam UU Pengairan terdapat pengaturan bahwa badan hukum atau badan sosial atau perorangan dapat melakukan pengusahaan air dan atau sumber-sumber air dengan syarat harus memperoleh izin dari Pemerintah. Hal ini menunjukkan bahwa negara tidak bisa secara mutlak menguasai dan mengelola secara mandiri sumber daya air, masih perlunya kontribusi oleh pihak swasta untuk mengelola sumber daya air tersebut.

PP PSDA yang notabe nya sebagi peraturan pelaksana dari UU Pengairan juga memberikan pengaturan yang sejalan dengan apa yang disebut dalam Pasal 11 UU Pengairan, bahwasanya Pengusahaan Sumber Daya Air pada dasarnya di lakukan oleh negara atau pemerintah melalui badan usaha milik negara, badan usaha milik daerah, badan usaha milik desa, namun juga bias dilakukan oleh badan usaha swasta, koperasi, perseorangan, kerja sama antar badan usaha.

Berlakunya PP PSDA masih mengatur keterlibatan pihak swasta dalam proses pengelolaan sumber daya air, hal ini tentunya kembali memberikan peluang bagi pihak swasta menguasai dan mengusahakan air dengan tujuan untuk mendapatkan keuntungan secara pribadi bukan digunakan untuk pelayanan kepada masyarakat demi kesejahteraan, artinya PP PSDA merupakan swastanisasi terselubung dan pengingkaran tafsir konstitusional Mahkamah Konstitusi, ${ }^{2}$ yang dapat melahirkan mindset (pola pikir) pengelola air yang selalu profit oriented atau mengedepankan keuntunga, padahal Mahkamah Konstitusi memberikan penafsiran bahwa hak guna air merupakan konsep yang bertentangan dengan UUD NRI 1945 namun dalam PP PSDA yang menjadi peraturan pelaksana UU Pengarian kembali menerapkan konsep pengusahaan sumber daya air yang dapat diberikan kepada swasta. Maka perlu dikaji lebih lanjut mengapa hak guna air dalam UU SDA dinyatakan bertentangan dengan UUND NRI 1945 oleh Mahkamah Konstitusi namun dalam

\footnotetext{
${ }^{2}$ Hukum Online, 'Mahkamah Konstitusi Ogah Membatalkan UU Sumber Daya Air' (Hukum Online, 2005) <https://www.hukumonline.com/berita/baca/hol13206/mahkamah-konstitusi-iogahi-membatalkan-uu-sumber-daya-air/> accessed 1 May 2019.
} 
UU Pengairan serta pengaturan baru terkait Pengelolaan sumber daya air dalam PP PSDA masih terdapat pengaturan pengusahaan sumber daya air oleh pihak swasta.

\section{Ratio Decidendi Putusan Mahkamah Konstitusi Nomor 85/PUU-XI/2013.}

Pada dasarnya semua undang-undang maupun regulasi yang bersifat mengatur dalam negara ini mengacu pada konstitusi, dimana konstitusi pada hakikatnya merupakan sebuah hukum dasar yang tertinggi, dan menjadi dasar bagi berlakuknya peraturan perundang-undangan lainnya yang lebih rendah. ${ }^{3}$ seperti jika di Indonesia ada UUD NRI 1945 sebagai dasar atau konstitusi negara, yang di dalamnya telah mengatur berbagai macam aspek dasar bernegara. Salah satu yang di amanatkan di dalamnya adalah mengenai hak menguasai negara dan kesejahteraan masyarakat Indonesia. Hal tersebut diatur dalam pasal 33 ayat (3) yang mengatur penguasaan negara atas Bumi dan air dan kekayaan alam yang terkandung didalamnya dan dipergunakan untuk sebesar-besarnya kemakmuran rakyat. Dari bunyi pasal 33 ayat (3) Undang-Undang Dasar 1945,

Sumber daya air yang disebut didalam pasal 33 (Ayat) 3 UUD NRI 1945 merupakan objek public good karena Sifat ekonomi air yang rivalrous (yaitu air merupakan sumber daya yang terbatas, penggunaan air oleh seseorang akan mengurangi ketersediaan air bagi orang lain), di sisi lain air semakin mengharuskannnya ditempatkan sebagai benda milik publik sebagai lawan dari barang milik pribadi, oleh sebab itu negara dalam hal ini seyogyanya memberikan regulasi terhadap pengelolaan sumber daya air yang ada di Indonesia, ${ }^{4}$ dengan demikian penguasaan privat atas sumber daya air dapat dicegah oleh hukum.

Amanat Pasal 33 Ayat (3) UUD NRI 1945 juga telah termaktub dalam Undang-Undang Nomor 5 Tahun 1960 tentang Peraturan Dasar Pokok-pokok Agraria (selanjutnya disebut UUPA). Pasal 2 UUPA diatur bahwa hak menguasai

\footnotetext{
3 Jimly Asshiddiqie, Pengantar Ilmu Hukum Tata Negara (Rajawali Pers 2015).[114].

${ }^{4}$ Sentot Sudarwanto, 'Dampak Dibatalkannya Undang-Undang Nomor 7 Tahun 2004 Tentang Sumber Daya Air Terhadap Manajemen Air Untuk Kesejahteraan Masyarakat' (2015) 4 Jurnal Yustisia.[463].
} 
dari Negara memberi wewenang untuk:

a. Mengatur dan menyelenggarakan peruntukan, penggunaan, persediaan, dan pemeliharaan bumi, air dan ruang angkasa;

b. Menentukan dan mengatur hubungan-hubungan hokum antara orangoreng dengan bumi, air, dan ruang angkasa;

c. Menentukan dan mengatur hubungan-hubungan hokum antara orangorang dan perbuatan-perbuatan hukum yang mengenai bumi, air, dan ruang angkasa.

Selain itu UUPA juga memberikan hubungan hukum antara negara sebagai organisasi kekuasaan seluruh rakyat Indonesia dengan bumi, air, ruang angkasa, dan kekyaan alam yang terkandung didalamnya, atas dasar hak menguasai tersebut negara dapat :

a. Menentukan bermacam-macam hak katas tanah;

b. Mengatur pengambilan kekayaan alam yang terkandung didalamnya;

c. Membuat perencanaan atau planning mengenai penyediaan, peruntukan dan penggunaan bumi, air, ruang akngkasa, dan kekayaan alam yang terkandung didalamnya;

d. Mencabut hak-hak atas tanah untuk keperluank kepentingan umum;

e. Menerima kembali tanah-tanah yang ditelantarkan, dilepaskan, subyek hak tidak memenuhi persyratan;

f. Mengusahakan agar usaha-usaha di lapangan agrarian diatur sedemikian rupa sehingga meningkatkan produksi dan kemakmuran rakyat.

Selain apa yang berkaitan dengan tanah UUPA juga memberikan sedikit pengaturan terkait air bahwasanya konsep hak menguasai negara dalam konteks pasal 33 Ayat (3) menempatkan air sebagai hak public semakin kental untuk memberikan manfaat dan sebesar-besarnya kesejahteraan rakyat maka hak negara mengatur segala aspek terkait pengelolaan dan peruntukannya.

Seperti yang telah dijelaskan sebelumnya bahwa sumber daya air pada mulanya diatur Undang-Undang Nomor 11 tahun 1974 tentang Pengairan, hingga muncul Undang-Undang Nomor 7 Tahun 2004 tentang Sumber Daya Air yang menggantikan UU Pengairan, UU SDA yang menjadi pengganti diharapkan lebih mengakomodir kepentingan-kepentingan rakyat Indonesia akan kebutuhan air serta diharapkan dapat lebih spesifik mengatur mengenai definisi air, pendayagunaan, konservasi, perencanaan, bahkan pengelolaan air oleh lembaga atau badan-badan 
usaha pemerintah, antara lain Pemerintahan Pusat, Provinsi dan Kabupaten/ Kota, hingga Pemerintahan Desa yang memiliki kewenanganya terhadap sumber daya air. Semuanya diatur dalam Undang-Undang Nomor 7 Tahun 2004 Tentang Sumber Daya Air.

Namun Dengan adanya putusan Mahkamah Konstitusi Nomor 85/PUUXII/2013 yang membatalkan Undang-Undang Nomor 7 Tahun 2004 tentang Sumber Daya Air . Akhirnya berlakulah kembali Undang-Undang Nomor 11 tahun 1974 tentang Pengairan. Dalam konteks substansi hukum yang menjadi permasalahan ialah faktor pluralism hukum yang memberikan ruang bagi terjadinya disharmoni hukum, ${ }^{5}$ hal ini mengakibatkan tidak sejalannya antara konstitusi dengan peraturan dibawahnya yakni dalam level Undang-undang dan peratruan lain dibawahnya.

Putusan Mahkamah Konstitusi Nomor 85/PUU-XI/2013, yang menjadi pokok permasalahan ialah adanya pengaturan yang bertentangan dengan UUD NRI 1945, yakni adanya konsep hak guna air yang memungkin-kan pihak swasta mengelola sumber daya air, sedangkan dalam UUD NRI 1945 Pasal 33 telah jelas diatur bahwa bumi dan air dan kekayaan yang ada didalamnya dikuasai oleh negara serta digunakan sebesar-besarnya untuk kesejahterann rakyat, maka dari itu dalam Putusan Nomor Mahkamah Konstitusi berpendapat :

Menurut pasal 33 ayat (2) dan (3) UUD NRI 1945 Menegaskan bahwa pemaknaan bahwa bumi dan air dan kekayaan alam yang terkandung di dalamnya dikusai oleh negara dan dipergunakan sebesar-besarnya untuk kemakmuran. Mengamanatkan bahwa air adalah salah satu unsur yang sangat penting dan mendasar dalam hidup dan kehidupan manusia atau menguasai hajad hidup orang banyak, maka untuk itu air haruslah dikuasai oleh negara.

Penafsiran-penafsiran lain terkait undang-undang sumber daya air sebagai pengujian terhadap UUD NRI 1945 terdapat pada Pasal 6 ayat (1) sampai (4), pasal 7 ayat (1) dan (2), dan pasal 9 ayat (1) sampai (3), dalam pasal tersebut terdapat inkonsistenti baik antar UU SDA dengan UUD NRI 1945 maupun pengaturan antar pasal dalam UU SDA itu sendiri. Seperti pada pasal 6 yakni tentang pengelolaan

${ }_{5}^{5}$ Jazim Hamidi, Muhammad Sinal, Ect, Teori Negara Hukum (A Turning Point of the State) (Salemba Humanika 2012).[77]. 
sumber daya air oleh negara yang memang selaras dengan yang ada di pasal 33 UUD NRI 1945, tetapi dalam pasal selanjutnya, mendiskripsikan adanya bentuk hak guna air yang terbagi atas 2 macam, yaitu hak guna pakai, dan hak guna usaha. Pelaksanaan dari hak guna usaha ini lah yang dianggap bertentangan dari pasal 6 undang-undang sumber daya air. Pasal 9 ayat (1) mengatur adanya hak guna usaha yang dapat diberikan kepada badan usaha atau perorangan dengan izin dari pemerintah atau pemerintah daerah. Karenanya penguasaan sumber daya air yang semula dimiliki oleh Negara dengan mengacu pada UU SDA penguasaan sumber daya air tersebut dapat dialihkan atau dipindah tangankan kepada badan usaha atau perorangan. Untuk itu Mahkamah Konstitusi menafsirkan adanya hak guna air sebagai berikut:

Konsep Hak Guna Pakai Air dalam Undang-Undang Sumber Daya Air harus ditafsirkan sebagai turunan (derivative) dari hak hidup yang dijamin oleh UUD 1945. Oleh karenanya, pemanfaatan air diluar Hak Guna Pakai Air dalam hal ini Hak Guna Usaha Air, haruslah melalui Permohonan izin kepada Pemerintah yang penerbitannya harus berdasarkan pada pola yang disusun dengan melibatkan peran serta masarakat yang seluas-luasna. Oleh karena itu, Hak Guna Usaha Air tidak boleh dimaksudkan sebagai pemberian hak penguasaan atas sumber air, sungai, danau, atau rawa. Hak Guna Usaha Air merupakan instrument dalam sistem perizinan yang digunakan Pemerintah untuk membatasi jumlah atau volume air yang dapat diperoleh atau diusahakan oleh yang berhak sehingga dalam konteks ini, izin harus dijadikan instrument pengendalian, bukan instrument penguasaan. Dengan demikian, swasta tidak boleh melakukan penguasaan atas sumber air atau sumber daya air tetapi hanya dapat melakukan penguasaan dalam jumlah atau lokasi tertentu saja sesuai dengan lokasi yang ditentukan dalam izin yang diberikan oleh Negara secara ketat.

Dengan kata lain, pemberian hak guna air ini sebagai sarana dalam melindungi hak konstitusional rakyat dalam hal pengelolaan air, harus dengan konsep res commune yang tidak boleh menjadi objek harga secara ekonomi. Air adalah sebagai alat pemenuh kebutuhan, bukan barang yang dinilai secara ekonomis. Dengan begitu meski terdapat hak guna usaha air melalui proses perizinan dari pemerintah, haruslah ditinjau secara benar proses penyediaan tersebut, apakah sudah sesuai dengan konsep yang sudah ditetapkan. Agar nantinya pengolaan tersebut bukan berdasar keuntngan semata. 


\section{Konsep Pengelolaan Sumber Daya Air Pasca Putusan Mahkamah Konstitusi Nomor 85/PUU-XI/2013}

Bagir Manan menyebutkan bahwa negara berdasarkan konstitusi mengandung sekurang-kurangnya dua makna yaitu pertama, pengaturan mengenai batas peran negara atau pemerintah dalam mencampuri kehidupan dan pergaulan masyarakat, kedua jaminan hukum dan hak-hak, naik sipil maupun hak-hak pribadi, hak-hak politik, maupun hak-hak sebuah kelompok atau sosial. ${ }^{6}$ Artinya ialah selain negara harus mementingkan hak konstitusional setiap warga harus terpenuhi, negara juga harus memberikan batasan terhadap peran sertanya dalam kehidupan masyarakat, namun dalam hal ini negara bukan memberikan kebebasan sepenuhnya, namun harus menciptakan keseimbangan antara ketertiban, kekuasaan, dan kebebasan, ${ }^{7}$ oleh sebab itu, kekuasaan negara harus tetap berdiri tegak disamping menjamin kebebasan individu warga negara, untuk mencipatakan sebuah ketertiban. ${ }^{8}$ Selain itu negara juga bertujuan untuk mengatur kepentingan umum demi terwujudnya kesejahteraan ${ }^{9}$. Dalam konteks pengelolaan sumber daya air dikarenakan ini menjadi hajat hidup orang banyak tentunya negara harus memberikan sikap mengatur serta membatasi bukan pada negara namun juga pada rakyat untuk tidak menggunakan sumber daya air untuk kepentingan pribadi apalagi untuk diusahakan, jadi negara memiliki peran mengatur batasan-batasan tersebut, sehingga seluruh masyarakat mendapatkan hak yang seharusnya mereka dapatkan.

Indonesia sendiri merupakan negara yang memiliki ketersediaan air yang cukup besar per kapitanya, tetapi sebagian besar air tersebut belum dikelola secara baik, dan masi banyak yakni puluhan juta warga yang belum bias meng-akses air bersih, ${ }^{10}$ perhitungan itu menggunakan kriteria Millennium Development

\footnotetext{
${ }^{6}$ Bagir Manan, Teori Dan Politik Konstitusi (FHUII Press 2003).[244-245].

7 Jimly Asshiddiqie (n 3).Op. Cit. [120].

8 Ibid.[120].

9 Ibid. [119].

${ }^{10}$ Herry Kamaroesid, Tata Cara Pendirian Dan Pengelolaan Badan Usaha Milik Desa (Mi-
} tra Wacana Media 2016).[46]. 
Goals (MDGs) Indonesia untuk air bersih, dan dari data sensus pada tahun 2010 hingga 2015, Bappenas menunjukkan bahwa Indonesia dalam proporsi rumah tangga dengan akses terhadap air minum layak, baik perkotaan maupun pedesaan hanya sebesar $47,71 \%$ sehingga untuk Indonesia dengan kapasitas air per kapita yang besar Indonesia butuh tambahan sekitar 36, 3 juta orang untuk mendapatkan air bersih sesuai dengan indeks per kapita atas ketersediaan air tersebut. ${ }^{11}$ Namun seperti yang telah diungkapkan air tersebut belum dikelola secara optimal sehingga dengan data yang telah ditampilkan tidak semua orang dapat merasakan atau mendapat layanan air bersih dengan baik. Meskipun ditunjang dengan warga kelas atas dan kelas menengah yang mampu menyediakan air secara mandiri namun pada dasarnya negara lah yang memiliki tanggung jawab terhadap ketersediaan air bagi warga. ${ }^{12}$

Setelah UU Pengairan kembali berlaku untuk menghindari kekosongan hukum dalam pengaturan pengelolaan sumber daya air, pemerintah mengesahkan Peraturan Pemerintah Nomor tentang Pengelolaan Sumber Daya Air (PP PSDA), tentunya dalam hal proses pembentukan peraturan pemerintah disini pemerintah harus mempertimbangkan Putusan Mahkamah Konstitusi yang telah menyatakan UU SDA tidak memiliki kekuatan hukum mengikat, sehingga tidak bertentangan dengan hak menguasai negara serta hak masyarakat terhadap sumber daya air.

Terdapat sedikit perbedaan pengaturan dalam UU SDA dan UU Pengairan, bahwasanya dalam UU SDA pengelolaan sumber daya air dilakukan melalui Hak Guna Air yang merupakan hak untuk memperoleh dan memakai atau mengusahakan air untuk berbagai keperluan, hak guna air ini dimiliki setiap rakyat Indonesia atas sumber daya air yang terdapat dalam wilayah negara Indonesia hak guna air ini terbagi menjadi 2 yakni hak guna pakai air dan hak guna usaha air dimana hak guna pakai air merupakan hak untuk memperoleh dan memakai air, sedangkan hak guna usaha air merupakan hak untuk memperoleh dan mengusahakan air, dan juga merupakan instrumen dalam sistem perizinan yang digunakan Pemerintah

\footnotetext{
11 ibid. [46].

12 ibid. [46].
} 
untuk membatasi jumlah atau volume air yang dapat diperoleh atau diusahakan oleh yang berhak. ${ }^{13}$

Jika ditinjau dari definisi terhadap kedua hak guna air tersebut dapat dibedakan dari unsur hak nya bahwa hak guna pakai hanya merupakan hak untuk memperoleh serta memakai air, tentunya dalam memperoleh dan menggunakan air untuk keperluan pribadi perorangan tidak membutuhkan suatu izin tertentu karena sudah menjadi hak setiap orang untuk memperoleh serta memakai atau menggunakan air untuk kebutuhan sehari-hari mereka, namun berbeda jika hak guna pakai ini digunakan untuk keperluan kelompok tertentu yang membutuhkan jumlah atau ketersediaan air yang banyak, atau untuk pertanian yang menggunakan air diluar sistem irigasi yang sudah ada dan dengan mengubah kondisi sumber air yang sudah ada.

Ketentuan penggunaan sumber daya air untuk keperluan tersebut harus menggunakan izin dari pemerintah pusat atau daerah sesuai kewenangannya. Sedangkan hak guna usaha selain dapat memperoleh dan tentunya memakai air hak guna usaha juga dapat digunakan untuk mengusahakan air, yang dimaksud mengusahakan disini adalah hak untuk memenuhi kebutuhan usaha, baik penggunaan air untuk bahan baku produksi, pemanfaatan potensinya, media usaha, maupun penggunaan air untuk bahan pembantu produksi. Hak Guna Usaha ini didapat dari izin pemerintah pusat atau pemerintah daerah sesuai kewenangannya.

Tabel 1. Uraian Tentang Hak Guna (Dep Kimpraswil, 2004) ${ }^{14}$

\begin{tabular}{|c|c|c|c|c|}
\hline Jenis Hak & $\begin{array}{c}\text { Cara } \\
\text { Memperoleh }\end{array}$ & Subyek & Tujuan & Persyaratan \\
\hline \multirow{2}{*}{$\begin{array}{l}\text { Hak Guna } \\
\text { Pakai (Tanpa } \\
\text { Izin) }\end{array}$} & \multirow{2}{*}{ Tanpa Izin } & $\begin{array}{l}\text { Perorangan } \\
\text { Perorangan }\end{array}$ & $\begin{array}{l}\text { Kebutuhan Pokok } \\
\text { Sehari-hari }\end{array}$ & \multirow{2}{*}{$\begin{array}{l}\text { Tidak mengubah } \\
\text { kondisi sumber } \\
\text { air }\end{array}$} \\
\hline & & Kelompok & $\begin{array}{l}\text { Pertanian rakyat } \\
\text { dalam jaringan irigasi } \\
\text { yang sudah ada }\end{array}$ & \\
\hline
\end{tabular}

${ }^{13}$ Irfan Nur Rahman, 'Implikasi Hukum Putusan Mahkamah Konstitusi Tentang Pengujian Konstitsionalitas Undang-Undang Sumber Daya Air' (2015) 20 Kajian Juni.[118].

14 Robert. J. Kodoatie dan M. Basoeki, Kajian Undang-Undang Sumber Daya Air (ANDI 2005).[39]. 


\begin{tabular}{|c|c|c|c|}
\hline \multirow{2}{*}{$\begin{array}{l}\text { Hak Guna } \\
\text { Pakai (dengan } \\
\text { Izin) }\end{array}$} & \multirow{2}{*}{ Dengan Izin } & $\begin{array}{l}\text { Perorangan atau } \\
\text { Kelompok }\end{array}$ & $\begin{array}{l}\text { Pertanian diluar } \\
\text { jaringan irigasi yang } \\
\text { sudah ada }\end{array}$ \\
\hline & & Kelompok & $\begin{array}{l}\text { Kebutuhan Pokok } \\
\text { sehari-hari dan } \\
\text { kebutuhan social }\end{array}$ \\
\hline $\begin{array}{l}\text { Hak Guna } \\
\text { Usaha }\end{array}$ & Dengan Izin & $\begin{array}{l}\text { Perorangan / } \\
\text { Kelompok / } \\
\text { Badan Usaha }\end{array}$ & $\begin{array}{l}\text { Untuk memenuhi } \\
\text { kebutuhan usaha }\end{array}$ \\
\hline
\end{tabular}

Dari tabel tersebut dapat diketahui adanya konsep pengelolaan sumber daya air yang dilakukan oleh badan usaha swasta dengan diberikannya gak guna usaha air yang pengelolaan sumber air tersebut murni hanya untuk memenuhi kebutuhan usaha bahkan dengan secara langsung memanfaatkan sumber daya air tersebut untuk diusahakan atau untuk memperoleh keuntungan. Untuk itu Mahkamah Konstitusi dalam putusannya memberikan penafsiran terkait hak guna usaha. Bahwa hak guna usaha air tidak boleh di maksudkan untuk memperoleh penguasaan penuh terhadap sumber daya air, hal ini harus dibedakan dengan adanya konsep Hak Guna Usaha atas tanah yang dapat dimiliki oleh perorangan atau pun badan hukum, sedangkan dalam konsep hak guna usaha air yang menjadi objek penguasaannya adalah air yang merupakan unsur terpenting dalam kehidupan manusia sebagai hak seluruh rakyat dan kebutuhan bagi setiap rakyat.

Beralih kepada UU Pengairan yang saat ini kembali berlaku setelah UU SDA dibatalkan oleh Mahkamah Konstitusi. Konsep pengelolaan dalam UU Pengairan tentunya harus berdasarkan UUD NRI 1945 dengan hak penguasaan oleh negara, Mengingat kedudukan air sebagai economic good berkaitan langsung dengan fakta bahwa air sebagai suatu sumber daya telah, sedang dan akan menjadi barang yang semakin langka, yang melatarbelakanginya ialah jumlah cadangan air yang tidak merata di antara satu wilayah dengan wilayah lain, dan juga air dipandang sebagai suatu hal yang vital dalam pembangunan ekonomi dan sosial, ${ }^{15}$ oleh sebab itu negara berwenang dalam harus mengatur, mengelola, serta menetapkan izin

${ }^{15}$ Akhmad Fauzi, Ekonomi Sumber Daya Alam Dan Lingkungan (Gramedia Pustaka Utama 2004).[165]. 
terhadap pengelolaan sumber daya air yang menjunjung kesejahteraan seluruh rakyat Indonesia.

Izin sebagai salah satu tindakan hukum pemerintah yang berdasarkan undangundang untuk diterapkan pada peristiwa konkret menurut prosedur dan persyaratan tertentu ${ }^{16}$ menjadi salah satu kontrol pemerintah ${ }^{17}$ atas tindakan tertentu yang akan dilakukan oleh masyarakat. Tidak terkecuali dalam izin pengelolaan sumber daya air, yang pada dasarnya pengelolaan sumber daya air ditujukan untuk kesejahteraan rakyat dilakukan oleh pemerintah baik pusat maupun daerah, namun terdapat konsep pengusahaan sumber daya air yang dapat diberikan kepada Badan Hukum, Badan Sosial dan atau perorangan dengan pengelolaan yang berazas usaha bersama dan kekeluargaan. Pengaturan ini dapat memberikan hak atau izin kepada swasta untuk mengelola sumber daya air, tentunya izin yang diberikan seperti yang sebelmnya dijelaskan harus berdasarkan undang-undang dan telah melalui prosedur serta memenuhi syarat tertentu.

Pengusahaan sumber daya air ini lebih lanjut diatur dalam Peraturan Pemerintah Nomor 121 tahun 2015 tentang Pengusahaan Sumber Daya Air (PP PSDA), dalam Pasal 1 Angka (9) dijelaskan yang dimaksud dengan Pengusahaan Sumber Daya Air adalah upaya pemanfaatan Sumber Daya Air untuk memenuhi kebutuhan usaha. Setelah dibatalkannya UU SDA yang didalamnya terdapat konsep Hak Guna Usaha Air yang dianggap betentangan dengan konstitusi, namun setelah kembali pada UU Pengairan dan dibuat peraturan pelaksananya melalui PP PSDA masih ada konsep Pengusahaan Sumber Daya Air yang secara definisi tidak jauh berbeda dengan Hak Guna Usaha Air yakni untuk memenuhi kebutuhan Usaha. Selain itu konsep pengusahaan sumber daya air ini juga masih dapat diberikan kepada badan usaha selain dari pemerintah pusat/daerah, dalam pasal 13 Ayat (2) PP PSDA menyebutkan badan-badan usaha yang dapat melakukan pengusahaan sumber daya air antara lain badan usaha milik negara, badan usaha milik daerah, badan usaha milik desa, badan usaha swasta, atau kerja sama antar badan usaha dan bisa juga diberikan kepada perorangan.

\footnotetext{
${ }^{16}$ Ridwan HR, Hukum Administrasi Negara (Rajawali Pers 2016).[201].

17 ibid.[201].
} 
Jika melihat dari definisi dan pengaturan yang memberikan kesempatan terhadap pihak swasta untuk mengelola sumber daya air maka pengusahaan sumber daya air yang telah diatur dalam PP PSDA tak ubahnya dengan hak guna usaha air yang telah diatur dalam UU SDA namun hal ini perlu dicermati kembali karena tentunya pemerintah telah memberikan pertimbangan dari putusan Mahkamah Konstitusi ketika membentuk sebuah peraturan perundang-undangan khususnya terhadap peraturan pengelolaan sumber daya air ini.

Pasal 33 UUD NRI 1945 merupakan roh dari atau dasar dari pengaturan pengelolaan sumber daya air, pasal ini memberikan wewenang negara sebagai organisasi kekuasaan seluruh rakyat untuk mengatur hal-hal yang sehubungan dengan air, ${ }^{18}$ tentunya juga dengan pengelolaan sumber daya air. Maka dari itu penguasaan terhadap bumi, air dan kekayaan alam yang terkandung didalamnya pada tingkatan tertinggi dikuasai oleh negara. Dikuasai dalam hal ini memiliki arti memiliki secara mutlak namun negara memiliki hak yang berdasarkan hak bangsa untuk secara penuh mengelola, mengatur, memanfaatkan, penggunaan, serta mengusahakan air dimana segala bentuk perlakuan pemerintah tersebut bertujuan untuk sebesar-besarnya kesejahteraan rakyat. ${ }^{19}$

Oleh sebab itu pengelolaan sumber daya air ini harus secara penuh dikontrol oleh pemerintah, namun bukan berarti pemerintah sendiri yang melakukan kegiatan pengelolaan sumber daya air, maka dari itu dalam PP PSDA pengusahaan sumber daya air dapat diberikan kepada pihak swasta tentunya dengan tata cara yang telah di tentukan dan syarat yang harus dipenuhi agar tidak bertentangan dengan hak menguasai negara khususnya dalam Pasal 33 UUD NRI 1945. Dalam Putusan Mahkamah Konstitusi Nomor telah dipaparkan pendapat-pendapat hakim dalam menafsirkan bagaimana hak menguasai negara ini diterapkan dalam peraturan perundang-undangan yang terkait. Seperti dalam pengelolaan sumber daya air bagaimana hak-hak konstitusional rakyat akan air dapat terpenuhi, dan tidak hanya

18 Sri Hajati dan Sri Winarsi, , Ect., 'Buku Ajar Politik Hukum Pertanahan'(. (Airlangga University Press) 2018).[53].

19 ibid.[55]. 
itu namun juga berkaitan dengan kesinambungan akan hak tersebut harus tetap dijamin oleh negara. Meskipun didalamnya terdapat konsep pengelolaan oleh pihak swasta namun pengelolaan tersebut harus berpedoman pada prinsip-prinsip pembatasan agar tidak muncul penguasaan sumber daya air oleh pihak swasta. Prinsip-prinsip tersebut antara lain: ${ }^{20}$

1. Setiap pengusahaan atas air tidak boleh mengganggu, mengesampingkan, apalagi meniadakan hak rakyat atas air karena bumi dan air dan kekayaan alam yang terkandung didalamnya selain harus dikuasai oleh negara, juga peruntukannya adalah untuk sebesar-besarnya kemakmuran rakyat;

2. Negara harus memenuhi hak rakyat atas air;

3. Harus mengingat kelestarian lingkungan hidup;

4. Sebagai implementasi hak menguasai negara dalam Pasal 33 UUD NRI 1945 Pengawasan dan pengengendalian oleh negara atas air sifatnya mutlak;

5. Prioritas utama yang diberikan pengusahaan atas air adalah BUMN dan BUMD.

Apabila setelah semua pembatasan tersebut diatas sudah terpenuhi dan ketersediaan air masi banyak, maka pemerintah dimungkinkan untuk memberikan izin kepada usaha swasta untuk melakukan pengusahaan air dengan syarat-syarat tertentuyang ditentukan. Khususnyayang perlu diperhatikan adalah memprioritaskan pengusahaan air tersebut kepada BUMN dan BUMD. sejauh ini hanya tercatat sekitar 402 PDAM (Perusahaan Daerah Air Minum) yang dimiliki oleh negara yang tersebar di sekitar 500 kabupaten/kota di Indonesia. ${ }^{21}$ Bahkan angka tersebut belum mencakup seluruh daerah Indonesia, jika di bandingkan dengan jumlah kabupaten dan kota di Indonesia yang berjumlah kisaran 500 kabupaten dan kota maka angka tersebut tidak mengakomodir sekitar 20\% dari jumlah kabupaten dan kota yang ada. Hal ini tentunya perlu dioptimalkan kembali.

Pembatasan pembatasan tersebut terdapat pada Pasal 2 PP PSDA sebagai peraturan pelaksanan dari UU Pengairan sehingga memenuhi syarat konstitusional dan dapat diterapkan. Prinsip-prinsip ini yang sebelumnya tidak ditemukan di dalam UU SDA sehingga Mahkamah Konstitusi memberikan amar putusan bahwa UU

\footnotetext{
${ }^{20}$ Putusan Mahkamah Konstitusi Nomor 85/PUU-XI/2013

${ }^{21}$ Herry Kamaroesid, Loc. cit.
} 
SDA bertentangan dengan UUD NRI 1945 dan dinyatakan tidak memiliki kekuatan hukum mengikat. sedangkan didalam PP PSDA dapat kita lihat harmonisasi pengaturan yang telah tercantum dalam PP PSDA dengan Ratio Decidendi dalam Putusan Mahkamah Konstitusi Nomor 85/PUU-XI/2013.

Tabel 2. Harmonisasi PP PSDA (data diambil dari Undang-undang dan dikelola oleh penulis)

\begin{tabular}{|c|c|}
\hline Prinsip Konstitualisme & Pasal dalam PP PSDA \\
\hline $\begin{array}{l}\text { tidak mengganggu, mengesamp- } \\
\text { ingkan, dan meniadakan hak rakyat } \\
\text { atas Air }\end{array}$ & $\begin{array}{l}\text { Pasal } 4 \text { Angka (3) } \\
\text { Pengusahaan Sumber Daya Air sebagaimana } \\
\text { dimaksud pada ayat (1) dapat diselenggarakan } \\
\text { apabila Air untuk kebutuhan pokok sehari- } \\
\text { hari dan pertanian rakyat telah terpenuhi, serta } \\
\text { sepanjang ketersediaan Air masih mencukupi }\end{array}$ \\
\hline $\begin{array}{l}\text { - } \quad \text { perlindungan negara terhadap hak } \\
\text { rakyat atas Air }\end{array}$ & $\begin{array}{l}\text { Pemerintah Menetapkan alokasi air demi } \\
\text { terpenuhinya kebutuhan air berdasarkan skala } \\
\text { prioritas } \\
\text { Pasal } 8 \\
\text { (1) Pemenuhan Air untuk berbagai kebutu- } \\
\text { han Sumber Daya Air dilakukan melalui } \\
\text { alokasi Air. } \\
\text { (2) Alokasi Air sebagaimana dimaksud pada } \\
\text { ayat (1) dilakukan berdasarkan prioritas } \\
\text { alokasi Air. } \\
\text { (3) Alokasi Air sebagaimana dimaksud } \\
\text { pada ayat (1) untuk memenuhi kebutu- } \\
\text { han pokok sehari-hari dan Air untuk iri- } \\
\text { gasi bagi pertanian rakyat dalam sistem } \\
\text { irigasi yang sudah ada merupakan pri- } \\
\text { oritas utama alokasi Air di atas semua } \\
\text { kebutuhan. } \\
\text { (4) Dalam hal jumlah Air tersedia tidak } \\
\text { mencukupi untuk pemenuhan prioritas } \\
\text { utama sebagaimana dimaksud pada ayat } \\
\text { (3), alokasi Air untuk pemenuhan kebu- } \\
\text { tuhan pokok sehari-hari lebih diprior- } \\
\text { itaskan daripada Air untuk irigasi bagi } \\
\text { pertanian rakyat dalam sistem irigasi } \\
\text { yang sudah ada. }\end{array}$ \\
\hline
\end{tabular}




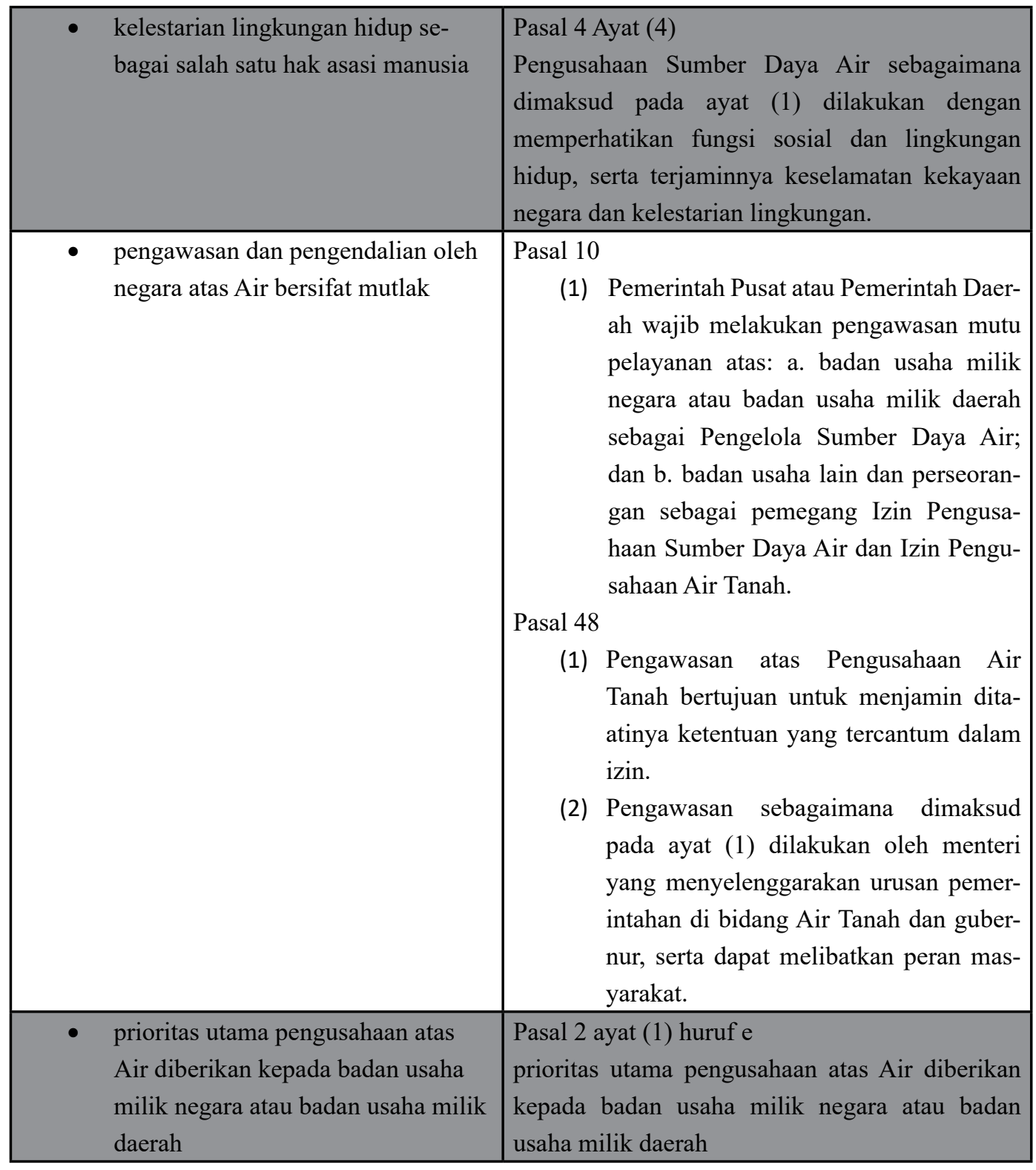

Dengan melihat tabel harmonisasi antara putusan Mahkamah Konstitusi dengan PP PSDA dapat diketahui bahwa pengelolaan sumber daya air yang diatur oleh PP PSDA memenuhi syarat konstitual sebagaimana yang telah ditetapkan oleh hakim Mahkamah Konstitusi atas Pasal 33 Ayat (3) UUD NRI 1945 khususnya terkait hak menguasai negara terhadap sumber daya air.

\section{Kesimpulan}

Mahkamah Konstitusi memberikan putusan menyatakan bahwa UU SDA bertentangan dengan UUD NRI 1945 dikarenakan adanya konsep hak guna usaha 
air yang didalamnya tidak memenuhi syarat konstitusionalitas terhadap hak menguasai negara atas sumber daya air. Selain itu UU SDA juga tidak memiliki batasan-batasan terhadap pengelolaan atau pengusahaan sumber daya air yang telah ditetapkan melalui Ratio Decidendi dalam Putusan Nomor yang batasan-batasan tersebut antara lain:

1. Tidak mengganggu, mengesampingkan, dan meniadakan hak rakyat atas Air;

2. Perlindungan negara terhadap hak rakyat atas Air;

3. Kelestarian lingkungan hidup sebagai salah satu hak asasi manusia;

4. Pengawasan dan pengendalian oleh negara atas Air bersifat mutlak;

5. Prioritas utama pengusahaan atas Air diberikan kepada badan usaha milik negara atau badan usaha milik daerah; dan

6. Pemberian Izin Pengusahaan Sumber Daya Air dan Izin Pengusahaan Air Tanah kepada usaha swasta dapat dilakukan dengan syarat tertentu dan ketat setelah prinsip sebagaimana dimaksud pada huruf a sampai dengan huruf e dipenuhi dan masih terdapat ketersediaan Air.

Setelah ada PP PSDA yang menjadi peraturan pelaksana UU Pengairan akhirnya syarat konstitusionalitas dalam pelaksanaan pengelolaan atau pengusahaan sumber daya air serta syarat pembatasan-pembatasan terhadap izin pengusahaan sumber daya air yang diberikan kepada swasta dapat diatur dan diterapkan, dalam hal ini Pemerintah baik pusat maupun daerah harus lebih mendorong sektor pengusahaan air yang dilakukan oleh BUMN maupun BUMD, sehingga hak-hak konstitusional rakyat akan ketersediaan air dapat terpenuhi dengan baik, selain itu amanat pasal 33 Ayat (3) UUD NRI 1945 dimana hak negara untuk menguasai sumber daya air tercapai dengan melakukan pengelolaan atau pengusahaan oleh pemerintah sendiri baik pusat maupun daerah, sehingga campur tangan pihak swasta dapat diminimalisir.

Pemerintah juga dapat mengembangkan sistem pengelolaan atau pengusahaan sumber daya air berbasis desa dengan mnedorong masyarakat desa untuk mendirikan Badan Usaha Milik Desa yang dipergunakan untuk mengelola sumber daya air untuk nantinya dapat memberikan kesejahteraan yang sebesar-besarnya bagi masyarakat akan ketersediaan air. 


\section{Daftar Bacaan}

\section{Buku}

Akhmad Fauzi, Ekonomi Sumber Daya Alam Dan Lingkungan (Gramedia Pustaka Utama 2004).

Bagir Manan, Teori Dan Politik Konstitusi (FHUII Press 2003).

Herry Kamaroesid, Tata Cara Pendirian Dan Pengelolaan Badan Usaha Milik Desa (Mitra Wacana Media 2016).

Jazim Hamidi, Muhammad Sinal, Ect, Teori Negara Hukum (A Turning Point of the State) (Salemba Humanika 2012).

Jimly Asshiddiqie, Pengantar Ilmu Hukum Tata Negara (Rajawali Pers 2015).

Ridwan HR, Hukum Administrasi Negara (Rajawali Pers 2016).

Robert. J. Kodoatie dan M. Basoeki, Kajian Undang-Undang Sumber Daya Air (ANDI 2005).

Sri Hajati dan Sri Winarsi, , Ect., Buku Ajar Politik Hukum Pertanahan(Airlangga University Press) 2018).

\section{Jurnal}

Arrsa RC, 'Telaah Sociolegal Terhadap Terwujudnya Kedaulatan Hak Atas Sumber Daya Air' (2015) 4 Jurnal Rechtvinding.

Irfan Nur Rahman, 'Implikasi Hukum Putusan Mahkamah Konstitusi Tentang Pengujian Konstitsionalitas Undang-Undang Sumber Daya Air’ (2015) 20 Kajian Juni.

Sentot Sudarwanto, 'Dampak Dibatalkannya Undang-Undang Nomor 7 Tahun 2004 Tentang Sumber Daya Air Terhadap Manajemen Air Untuk Kesejahteraan Masyarakat' (2015) 4 Jurnal Yustisia.

\section{Laman}

Hukum Online, 'Mahkamah Konstitusi Ogah Membatalkan UU Sumber Daya Air' (Hukum Online, 2005). $<$ https://www.hukumonline.com/berita/baca/hol13206/mahkamahkonstitusi-iogahi-membatalkan-uu-sumber-daya-air/> accessed 1 May 2019.

\section{Putusan Pengadilan}

Putusan Mahkamah Konstitusi Nomor 85/PUU-XI/2013.

HOW TO CITE: Aqiel al Rosyid Noor dan Alfian Khunaefi, 'Konsep Pengelolaan Sumber Daya Air Pasca Putusan Mahkamah Konstitusi Nomor 85/PUU-XI/2013' (2019) Vol. 2 No. 1 Notaire. 